Running Head: Organization Giving and Consumer Donation

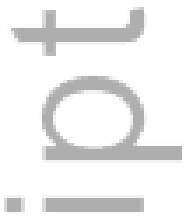

\author{
Dae Hee Kwak ${ }^{\mathrm{a}^{*}}$ \\ Youngbum Kwon
}

Author information:

${ }^{a^{*}}$ Dae Hee Kwak, Ph.D. (First author, corresponding author)

Assistant Professor, Department of Sport Management, University of Michigan

1402 Washington Heights, Ann Arbor, MI 48109

Telephone: 734-615-2884, Email: kwakd@umich.edu

${ }^{\mathrm{b}}$ Youngbum Kwon, Ph.D. (Second author)

Post-Doctoral Researcher, Department of Sport Management, University of Michigan

Telephone: 734-834-9335, Email: ybkwon@umich.edu

\title{
Biographical notes
}

Dae Hee Kwak is an Assistant Professor of Sport Management at the University of Michigan, USA, and a co-director of Michigan Center for Sport Management. He earned his Ph.D. in Sport Management from the University of Maryland, USA, and his research focuses on consumer behavior and consumer psychology with emphasis on examining cognitive and emotional factors influencing consumers' decision making and behaviors in various sport-related consumption contexts.

Youngbum Kwon is a Post-Doctoral Researcher in the Sport Management program at the University of Michigan, USA. His research interests include consumer behavior, brand

This is the author manuscript accepted for publication and has undergone full peer review but has not been through the copyediting, typesetting, pagination and proofreading process, which may lead to differences between this version and the Version of Record. Please cite this article as doi: 10.1002/cb.1576

This article is protected by copyright. All rights reserved. 
management, and sponsorship in the sports domain. Recently, he has conducted a series of research on examining the role of multidimnensional value on consuming sport team-licensed merchandise.

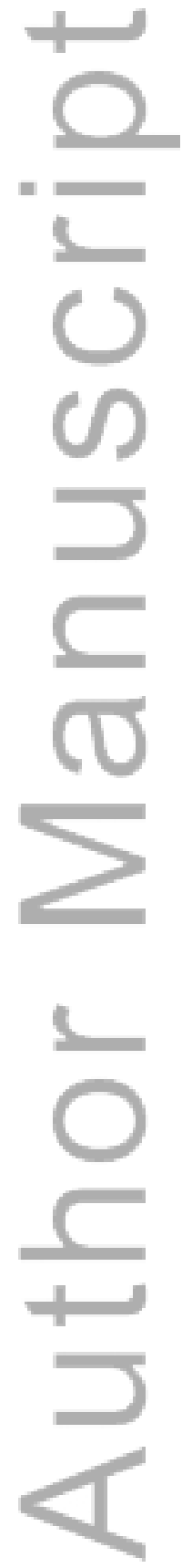

This article is protected by copyright. All rights reserved. 
Can an Organization's Philanthropic Donations Encourage Consumers to Give? The Roles of Gratitude and Boundary Conditions

\begin{abstract}
$+$
ABSTRACT

This study examines whether an organization's charitable donation will prompt consumers who closely identify with the organization to give to the charity as well. We posit that identifying with a benefactor will enhance the perception that consumers are involved in the donation process, which evokes grateful feelings. We also predict that the amount of the organization's donation will positively moderate the influence of organization identification on charity-evoked feelings of gratitude, while attitude toward the organization's charity will positively moderate the gratitude-donation relationship. In Study 1, we show how gratitude arises in the context of Corporate Social Responsibility (CSR) by demonstrating the mediating role of perceived donation contribution in the relationship between organization identification and gratitude. In Study 2, we demonstrate that organization identification has a significant indirect effect on donation intention through gratitude. Multigroup analyses show that the identification-gratitude link is more salient when the organization commits to donating a larger amount of money to a charity. Furthermore, the impact of gratitude on donation intent is significantly stronger for individuals who hold a favorable attitude toward the organization's CSR activity. Our findings indicate that an organization's charitable giving also encourages consumers to give to the community via vicariously felt gratitude.
\end{abstract}

This article is protected by copyright. All rights reserved. 
Keywords: social identification, gratitude, group-based emotion, charitable giving, consumer donation

Can an Organization's Philanthropic Donations Encourage Consumers to Give? The Roles of $=$ (1. Gratitude and Boundary Conditions

In 2014, individuals, corporations, and foundations in the U.S. gave \$335 billion to charity (givingUSAreports.org). Total charitable giving by American individuals makes up 72\% of all contributions received by nonprofit organizations. In 2013, per capita giving by U.S. adults reached \$1,016 and average U.S. household giving reached \$2,974 (Giving USA Foundation, 2014). Corporations also give to nonprofit organizations to practice corporate citizenship and to show that they give back to society. It is not uncommon for companies to partner with nonprofit organizations and further prompt consumers to give back to community. From placing a small donation box at the counter to creating a cause-related item, the proceeds from which go to a nonprofit organization, companies create various ways to increase the amount of money being donated to beneficiary organizations.

In professional sport, FC Barcelona has an agreement with UNICEF that is designed to donate at least $€ 1.5$ million per year to the United Nation's children agency. Such charitable giving has helped UNICEF to fund programs aimed at combating HIV and AIDS in Africa and Latin America (www.unicef.org). In addition, FC Barcelona contributed $€ 500,000$ in publicity 
assets to promote the partnership each year to remind football fans of the importance of children. Certainly, this philanthropic commitment of FC Barcelona might have helped increase awareness of the children's agency among football fans. Does such giving also increase individual giving among the soccer club's loyal fans? If so, what is the psychological mechanism that entices individual fans to donate to UNICEF? One area that has received relatively little attention is whether individual giving can be motivated by an organization's philanthropic giving. In particular, can an organization's giving encourage consumers who closely identify with the organization to donate more? The present study aims to find answers to these questions. Research findings have shown that such prosocial initiatives benefit organizations, particularly in terms of enhanced reputation and purchase intentions (e.g., Irwin et al., 2003; Roy and Graeff, 2003). However, little is known about whether an organization's charitable giving also encourages consumers to engage in philanthropic actions to benefit the organizationsupported charity (cf. Lichtenstein et al., 2004). We aim to extend the literature by examining whether an organization's Corporate Social Responsibility (CSR) actions can nudge consumers to follow prosocial behaviors, with benefits extending beyond the organization itself. We posit that feelings of gratitude induced by an organization's giving will play a critical role in inducing intentions to donate to the beneficiary of the philanthropic giving. Recent studies have shown that feelings of gratitude are not limited to an elicited norm of reciprocity (cf. Cialdini and Goldstein, 2004; Goldstein et al., 2011; McCullough et al., 2001, 2008), implying that gratitude can motivate prosocial behaviors beyond exchange or communal relationships (Algoe and Haidt, 
2009). Therefore, we posit that charity-induced gratitude to an organization is an important facilitator that will promote consumer donations to the beneficiary of the CSR.

In the CSR context, gratitude can arise when companies engage in prosocial actions such as protecting the environment, supporting social causes and resolving ethical dilemmas. Romani and colleagues (2013) found that gratitude is the typical positive moral emotion evoked in response to a company's moral and virtuous behaviors. In the current study, we extend this notion by proposing that individuals' strong identification with an organization engaged in CSR will be an important elicitor of such an emotional response. Consistent with the notion of groupbased emotions (Goldenberg et al., 2014), the more an individual identifies him or herself with the organization, the more the individual will experience gratitude due to an organization's CSR. We posit that this is because consumers who highly identify with the organization are more likely to associate themselves with the benefactor, which would evoke grateful feelings.

Therefore, we aim to extend the previous research by positing that a close psychological connection between the self and an organization (i.e., organization identification) will be an important source of charity-induced gratitude (e.g., Mackie et al., 2000; Yzerbyt et al., 2003). In addition, based on more recent theorizing on gratitude (e.g., Algoe et al., 2008; Bartlett and De Steno, 2006; Fredrickson, 2004), we posit that grateful individuals will move beyond a reciprocal relationship and support the beneficiary of the prosocial behavior. Thus, the present study contributes to the existing research by demonstrating how an organization's giving can encourage prosocial behaviors to benefit the community. 
In doing so, we further extend the literature by exploring two boundary conditions that moderate the organization identification-gratitude-donation relationship. First, we propose that the amount of an organization's donation will have a positive moderating effect on the organization-gratitude relationship. Second, we predict that a favorable evaluation of an organization's charitable giving will positively moderate the gratitude-prosocial behavior link. $=$ Therefore, our study contributes to the CSR and consumer behavior literature by considering additional context-specific boundary conditions (i.e., donation amount and attitude toward the charity) in examining the relationships between organization identification, gratitude, and donation intent. Our findings will also aid nonprofit managers partnering with sport properties in understanding the dynamic influence of organization identification on the construction of gratitude and its subsequent impact on benefiting the nonprofit through philanthropic giving.

\section{THEORETICAL BACKGROUND}

\section{Organization identification as a determinant of gratitude}

In the present study, we posit that individuals will experience gratitude even when they are not the direct beneficiaries of CSR. The concept of group-based emotions provides a theoretical explanation for how grateful feelings arise in the context of an organization's CSR activity. Group-based emotions refer to "emotions that are dependent on an individual's membership in a particular social group and occur in response to events that have perceived relevance for the group as a whole" (Goldenberg et al., 2014, p. 581). This approach integrates social identity theories (e.g., Tajfel and Turner, 1986) with appraisal theories (Lazarus, 1991), which offers a new perspective on how individuals experience emotional reactions to events 
associated with one's group membership. Goldenberg et al. (2014) asserts that group-based emotions are elicited by level of identification with the group. Further, several studies have found that people experience group-based emotions when the event is directly relevant to one's social identity (Kessler and Hollbach, 2005; Yzerbyt et al., 2003). A close psychological connection between the self and the organization will predispose individuals to appraise the event as personally relevant.

Although the idea of group-based emotions explains how individuals experience emotional reactions indirectly through a social identity, it does not explain why consumers would specifically feel gratitude when they are not the direct beneficiaries of a CSR activity. Earlier theorizing about gratitude asserts that people experience gratitude when they receive benefits from gifts, help, favors, or support from another person or entity (Tesser et al., 1968). Likewise, empirical research supports the notion that gratitude is generally elicited when an individual perceives that he or she is the direct beneficiary of another person or entity's moral action (Emmons and Crumpler, 2000; Haidt, 2003; McCullough et al., 2001).

However, more recent theorizing of gratitude asserts that gratitude can be elicited in the absence of a direct benefactor-beneficiary relationship (Haidt, 2003; Romani et al., 2013). For instance, Haidt (2003) proposes that gratitude is triggered by the good deeds of other people. Altruistic giving by a company (e.g., support for health programs, environmental issues, poverty, etc.) can generate feelings of gratitude in consumers, which promote prosocial behaviors. In the CSR context, Romani and colleagues (2013) showed that a company's CSR activity triggers gratitude even when the consumer is not the direct beneficiary of the prosocial activity. They 
contend that consumers can perceive benefits by considering organizations' initiatives in different domains as supporting one or more of their moral values. That is, consumers might construe CSR actions to be upholding or surpassing their desired moral values, which would facilitate the feelings of gratitude. Further, we propose that consumers who identify with the organization will consider the philanthropic giving to be personally relevant, which would evoke $=$ the perception that they also have contributed to the donation. Therefore, positive moral emotions of gratitude can result through enhanced perceived donation contributions, even in the absence of a direct or material benefit from the CSR (Romani et al., 2013). In turn, we posit that perceived donation contributions will evoked grateful feelings. In line with social identity theory and appraisal theories of emotions, we propose the following hypotheses:

Hypothesis 1: Organization identification will have a positive effect on perceived contribution in the donation process.

Hypothesis 2: Perceived contribution in the donation process will have a positive effect on gratitude.

Hypothesis 3: Organization identification will have a positive effect on gratitude.

\section{Feelings of gratitude and prosocial behavior}

According to McCullough et al. (2001), gratitude functions as a moral motive that urges individuals to behave prosocially themselves, either toward the benefactor, toward others, or both. Fredrickson (2004) further conceptualized that grateful individuals do not limit their actions simply to repaying a benefactor in a tit for tat manner. Rather, grateful individuals consider a wide range of prosocial actions directed to promoting the well-being of other people, 
above and beyond the original benefactor (Bartlett and De Steno, 2006; Fredrickson, 2004).

Similar findings support the view of that prosocial behaviors are not simply caused by the norm of reciprocity (Algoe et al., 2008; Algoe and Haidt, 2009; Cialdini and Goldstein, 2004). In this regard, some researchers distinguish gratitude from indebtedness, which implies an obligation and is often experienced as a negative state (Tangney et al., 2007).

In the present study, we conceptualize gratitude as a positive emotional state that has a moral motive function (McCullough et al., 2001), which promotes prosocial behaviors that move beyond mindless tit-for-tat behavior. Following Fredrickson's (2004) conceptualization of gratitude, we propose that gratitude will formulate actions that promote the well-being of other people, including, but not limited to, the original benefactor. Therefore, in the context of CSR, we posit that gratitude will be positively associated with donation intentions to support the beneficiary. We posit that consumers who are highly identified with the organization will feel grateful in response to their extended social identity's benevolence, and that this grateful feeling will motivate them to support the charity (beneficiary). Therefore, we propose the following hypotheses:

Hypothesis 4: Gratitude will have a positive effect on donation intention to support the beneficiary of the charity.

From a social exchange perspective, which is concerned with the processes that govern the transfer of social or psychological resources between a benefactor and beneficiary, it can be expected that an organization's charitable giving will signal prosocial behaviors among those who closely identify with the organization. The more an individual identifies him or herself with 
the organization, the more likely it is that the person will feel the need to engage in similar behavior and contribute to the organization-supported charity. In the organizational behavior literature, studies have found that organizational identification has a significant direct effect on various in-group prosocial behaviors (e.g., "I help new people even though it is not required"; Bell and Menguc, 2002; O'Reilly and Chatman, 1986). Given that strong organization identification motivates consumers to expend effort to benefit others and promote the welfare of the organization, we could also expect that organization identification will have a direct impact on prosocial behavioral intentions. Therefore, we hypothesize the following:

Hypothesis 5: Organization identification will have a direct positive effect on donation intention to support the beneficiary of the organization's charitable giving.

\section{Boundary condition: Organization's donation amount}

Based on the notion that organization identification is an important determinant of groupbased emotions (Kessler and Hollbach, 2005), we propose that the strength of the identificationgratitude relationship will depend on the amount that an organization donates to a charity. There have been studies examining the effect of donation amount on attitude- and behavior-related outcomes such as consumers' willingness-to-pay for charity-linked products (e.g., Folse, Niedrich and Grau, 2010; Haruvy and Popkowiski Leszczyc 2009; Koschate-Fischer, Stefan and Hoyer, 2012). For instance, Haruvy and Popkowski Leszczyc (2009) found that donation amount expressed as percentage of the auction revenue in a charity context increased participants' bidding and the auction revenues. Given that the amount of proceeds that went to a charity organization increased individuals' giving amount by promoting their bidding behavior, we 
contend that the organization identification-gratitude relationship will vary with the organization's donation amount. According to Palmatier et al. (2009), consumers' perception of a firm's investment increases feelings of gratitude, which then promote gratitude-related reciprocal behaviors in the relationship marketing context. Palmatier et al. emphasized consumers' perception of investment as a critical determinant of gratitude. As such, we contend that the larger the amount of money an organization commits to donating, the more likely it will be to increase consumer perceptions of investments, which would evoke greater feelings of gratitude. Therefore, we posit that an organization's donation amount will positively moderate the influence of organization identification on gratitude.

Hypothesis 6: An organization's donation amount will positively moderate the identification-gratitude relationship such that the effect of identification on gratitude will be greater when the organization donates a larger amount of money.

\section{Boundary condition: Attitude toward the organization's charity}

While the literature suggests that gratitude is a moral emotion closely associated with prosocial behaviors, we propose that individuals' attitude toward the organization's charity will strengthen the gratitude-donation intention relationship. This is because favorable evaluations of the organization's charity will function as a motivator to prompt grateful individuals to act upon their positive moral emotions. In a related study, Arora and Henderson (2007) found that positive cause evaluations influence consumers' choice of a purchase-contingent donation (charity incentive). Similarly, Lichtenstein and colleagues (2004) also found that personal relevance of cause has a positive impact on charity-linked product choice. Although these studies have not 
specifically examined donation intention, we posit that the gratitude-donation link will be strengthened (weakened) when consumers have more positive (less positive) attitudes toward the organization's charity activity. Given that the call to action we are considering is making a monetary donation to a local charity, we believe that the giving intention will be prompted even more when individuals have a favorable attitude toward the charity activity. Therefore, we predict that attitude toward the organization's charity will positively moderate the effect of gratitude on donation intention.

Hypothesis 7: Attitude toward the organization's charity will moderate the effect of gratitude on donation intention in that the gratitude-donation link will be more salient among individuals who favorably evaluate the charity program.

Two studies are presented to test the proposed hypotheses. Study 1 examines how gratitude arises in the context of CSR by examining the mediating role of perceived donation contribution. Study 2 examines the moderating roles of domain-specific variables (donation amount and attitude toward the CSR) in the identification-gratitude-donation relationship. We utilized the National Football League (NFL) as the research context because of its substantial economic and cultural impact in the U.S. market. The revenue of the NFL is estimated to be about $\$ 10$ billion per year and the overall market value of its 32 franchises is estimated to be more than $\$ 46$ billion (Bloomberg Business, 2014), which is about equal to one-sixth of the market capitalization of Walmart, the top grossing company on the Fortune 500 list (Fortune, 2015). An average of 17.6 million viewers watched regular season games on television, and 
more than 112 million people watched the Super Bowl (the final championship match at the end of the season) in 2014 (NFL, 2014), making it one of the most-viewed sporting events in the U.S. (NBC Sports, 2015). The spectator sport context provides unique opportunities for researchers to investigate the dynamic influence of organization identification on various consumer behaviors (e.g., Madrigal, 2001; Trail et al., 2005). Thus, the popular professional sport league is deemed = an appropriate context in which to examine the influence of organization identification on gratitude and subsequent prosocial behavior.

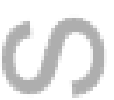

\section{STUDY 1}

This study was designed to examine how gratitude arises in the CSR context. We hypothesized that individuals' perceived donation contribution will mediate the influence of organization identification on gratitude. A close psychological connection with an organization will prompt individuals to perceive that they, too, have contributed to the giving. In particular, when a donation amount is contingent upon sales of merchandise or tickets (e.g., $5 \%$ of proceeds being donated to a charity), loyal consumers would believe that they have already made contributions to the organization's philanthropic giving. Therefore, we posit that organization identification will also increase perceived donation contribution, which will lead to grateful feelings.

\section{Participants and procedure}

The basic design of the study is a single factor two-level (proximity of charity: local vs. international) between subjects design. Participants $(\mathrm{N}=401)$ were recruited from a consumer panel from the Qualtrics Research Panel (51\% female, average age of 50 years), which was run on computers, in exchange for \$5. Participants were asked to complete the first part of a 
questionnaire, which included questions related to the general interest of the respondents toward their favorite team in the NFL. Participants were first asked to identify the NFL team that they follow. Then they were asked to rate their team identification level based on the team they selected. Participants then were randomly assigned to one of two scenario conditions (local charity Vs. international charity) announcing the team's new partnership with a local (international) food bank to which the team aims to donate marketing proceeds (See Appendix A for the scenario). After reading the scenario, participants completed questionnaires related to gratitude and perceived donation contribution.

\section{Measurements}

Team identification, gratitude, perceived donation contribution, and attitude toward helping others were measured in this study. Team identification was measured with Robinson and Trail's (2005) three-item scale (e.g., "Being a fan of the [team X] is very important to me"; $\alpha$ $=.95 ; M=4.48 ; S D=1.95)$. Gratitude was measured with Palmatier et al.'s (2009) three-item scale. This scale was originally adapted from McCullough et al. (2002) and consists of three items (e.g., "I feel grateful to [team X]"; $\alpha=.89 ; M=5.27 ; S D=1.55$ ). Finally, perceived donation contribution was measured with two items (e.g., "To what extent do you feel involved with the Team X's donation to the charity?"; $\alpha=.81 ; M=3.05 ; S D=1.74)$. Finally, attitude toward helping others, a control variable, was measured with four items (Webb et al., 2000) (e.g., "Helping troubled people with their problems is very important to me"; $\alpha=.92 ; M=5.73 ; S D=$ 1.07) (see Appendix B for all measures).

\section{Results and discussion}


We first assessed whether the proximity of the charity (local vs. international) had any effect on gratitude. Since proximity did not have any effect, we do not discuss this variable further $(p>.3)$. We utilized Hayes' (2013) regression analysis to examine the mediating role of perceived donation contribution on the effect of team identification on gratitude. We found that organization identification had a significant effect on perceived donation contribution $(b=.35, t$ $=10.44, p<.001)$, supporting H1. Results also showed that organization identification $(b=.27, t$ $=9.40, p<.001)$ and perceived donation contribution $(b=.30, t=9.44, p<.001)$ had significant effects on gratitude, supporting $\mathrm{H} 2$ and $\mathrm{H} 3$. Attitude toward helping others, a control variable, also had significant effects on the perceived donation process $(b=.15, t=2.53, p<.05)$ and gratitude $(b=.34, t=7.56, p<.001)$. These findings suggest that gratitude is a direct function of both organization identification and perceived donation contribution, while perceived donation contribution partially mediates the impact of identification on eliciting gratitude.

Findings from this study provide empirical evidence for the charity-evoked gratitude mechanism triggered by one's social identity and perceived donation involvement. The findings suggest that consumers feel gratitude in part due to perceiving themselves to be involved in the donation process. The more closely an individual identifies with the organization, the more likely it is that the person will believe he or she has contributed to the donation process. Considering that the donation amount is contingent upon sales of merchandise and tickets, it seems reasonable to believe that those who closely identify with the team would make more purchases related to the team and thus believe they have contributed to the giving. Our effects can be interpreted as evidence for a CSR-induced gratitude mechanism, explaining how consumers 
experience gratitude even when they are not the direct beneficiaries of the CSR (Romani et al., 2013). The next study considers two domain-specific boundary conditions (i.e., donation amount and attitude toward the CSR) that might affect the identification-gratitude-donation relationship.

\section{STUDY 2}

Study 2 was designed to further investigate the identification-gratitude-donation relationship by demonstrating the moderating roles of two boundary conditions: donation amount and attitude toward the CSR. We used a single factor two-level between subjects design (donation amount: high vs. low).

\section{Participants and procedure}

Participants ( $\mathrm{N}=201 ; 53 \%$ female, mean age of 51 years) were recruited from the subject pool from the Qualtrics Research Panel, via online survey, in exchange for \$5. Similar to Study 1, when participants agreed to participate in the study, they were asked to identify the NFL team that first came to their minds. Upon completion of the first phase, similar to Study 1, respondents were randomly assigned to one of two scenario conditions (1\% and $\$ 2$ million vs. $5 \%$ of proceeds and $\$ 10$ million given to the charity) depicting a charitable giving activity toward a local nonprofit organization undertaken by the team (see Appendix A). After reading the scenario, respondents completed questionnaires related to gratitude toward the team engaging in the charitable giving activity, attitude toward the charity, donation intention, and attitude toward helping others.

\section{Measurement}


Six variables (i.e., team identification, gratitude, donation intention, attitude toward organization's charity, attitude toward helping others, and perceived investment) were measured with multi-item scales $(1=$ strongly disagree; 7 = strongly agree; see Appendix B $)$. We used the same scales from study 1 for team identification $(M=3.51 ; S D=1.89)$ and gratitude $(M=4.90$; $S D=1.76)$. Attitude toward the organization's charity was measured with the following fouritem scale (Roy, 2011): "Overall, my attitude toward team X sponsoring the charity is bad/good; negativelpositive; unfavorable/favorable; and likable/unlikable (reversed item)"; $\alpha=.92 ; M=$ $5.44, S D=1.22$ ). Donation intention was measured using three items (Roy, 2011) (e.g., "It is likely that I will donate my money to Feeding America"; $\alpha=.95 ; M=4.65 ; S D=1.63)$. A threeitem perceived investment (Schlosser et al., 2006) scale was administered as a manipulation check (e.g., "The amount of effort invested by Team X into sponsoring Feeding America seems to be a great deal"; $\alpha=.94)$. Lastly, attitude toward helping others was measured again as a control variable $(M=5.64 ; S D=.99)$. Overall, the six variables used in this study showed acceptable alpha values, ranging from .89 to .95 , within similar ranges from previous literature (e.g., Palmatier et al., 2009; Robinson and Trail, 2005; Roy, 2011).

In terms of the relation between the means of demographic variables (i.e., gender, income, and age) and the main variables, the results showed significant mean differences only on gender (team identification: male $M=4.67, S D=1.91$, female $M=3.73, S D=2.02$; gratitude: male $M$ $=4.53, S D=1.77$, female $M=5.12, S D=1.55$; donation intention: male $M=4.32, S D=1.63$, female $M=4.80, S D=1.54 ;$ all $p \mathrm{~s}<.05)$.

\section{Manipulation check}

This article is protected by copyright. All rights reserved. 
In order to assess that the organization's donation amount (1\% and $\$ 2$ million vs. $5 \%$ of proceeds and \$10 million expected amount) to the charity was successfully manipulated as intended (see Appendix), mean perceived investment scores were compared between the two conditions. Results of a t-test found a statistically significant difference in the perceived investment between $1 \%$ of the proceeds $(M=4.37, S D=1.82)$ and $5 \%$ of the proceeds $(\mathrm{M}=$ 5.00, $\mathrm{SD}=1.63 ; t=-2.89, \mathrm{df}=199, p<.05)$.

\section{Measurement validity}

Measurement validity of each construct appearing in the structural model was conducted in two phases (Anderson and Gerbing, 1992) prior to estimating and testing the hypothesized structural paths. In the first phase, to obtain convergent validity of the scale, the composite reliability (CR) and average variance extracted (AVE) values were examined. As shown in Table 1, all items loaded significantly on their corresponding latent constructs. In the second phase, two tests were performed to evaluate the discriminant validity across all possible pairs of constructs. First, each maximum shared squared variance (MSV) score and average shared squared variance (ASV) of the four factors was less than its AVE score. Second, the square root of AVE exceeded the correlations of that construct and all others (Hair et al., 2010). All the constructs in the proposed model met the recommended level, thereby providing evidence of good psychometric properties of the scales (see Table 1).

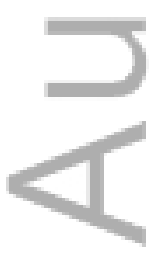

Place Table 1 about here 


\section{Results and discussion}

The study employed structural equation modeling to test the research hypotheses. Following the recommendations of Becker (2005), we analyzed the hypothesized model using the following steps. First, we added a control variable to the hypothesized model, and then compared results both with and without the control variable. Second, we eliminated a nonsignificant path to construct a parsimonious final model, and then tested the hypothesized model with the control variable since the model inclusive of the control variable showed slightly better fit indices. Finally, following the procedure outlined by Dabholkar and Bagozzi (2002), an overall chi-square difference test for a moderator variable was conducted.

In the first step, the model was estimated before and after the addition of the control variable (i.e., attitude toward helping others). Both models, with and without the control variable, provided similar results in terms of standardized regression coefficients and t-values (see Table 2). Of the three basic paths (i.e., H3 through H5), Hypotheses 3 and 4 were statistically significant $(p<.001)$, while Hypothesis 5 was not statistically significant $(p>.05)$ in both models. The fit of the model without the control factor $\left(\chi^{2} / \mathrm{df}=3.39 \mathrm{CFI}=.91 ; \mathrm{SRMR}=.03\right.$; RMSEA =.11) was less satisfactory than the fit indices of the model with the control variable included $\left(\chi^{2} / \mathrm{df}=2.22 ; \mathrm{CFI}=.97 ; \mathrm{SRMR}=.08 ; \mathrm{RMSEA}=.08\right)$. Considering these fit indices and the suggestions of Becker (2005), the model with the control variable was chosen for the next step.

Place Table 2 about here 
To develop a parsimonious final model, a non-significant path from organization identification to donation intention $(p>.05)$ was eliminated in the second step (cf. Gruen $e t a l$, 2000). After eliminating the path, the final model was retested. As shown in Table 3, the results of the parsimonious final model provide evidence of a good fit to the data $\left(\chi^{2} / \mathrm{df}=2.22 ; \mathrm{CFI}=.97\right.$; $\mathrm{NFI}=.94 ; \mathrm{SRMR}=.08 ; \mathrm{RMSEA}=.08 ; \mathrm{TLI}=.96)$. The results reveal that, with the exception of H5 $(\beta=.09, t=1.31)$, the other two hypothesized relationships are significant and in the theorized direction (H3: $\beta=.34, t=4.92 ; \mathrm{H} 4: \beta=.50, t=6.60)$. Finally, attitude toward helping others, a control variable, has a significant and positive effect on donation intention $(\beta=.30, t=$ $3.81)$.

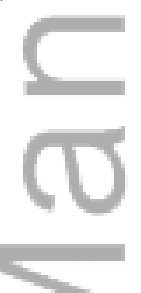

Place Table 3 about here

In the final step, the proposed moderator variables, attitude toward CSR (low vs. high) and donation amount (1\% vs. 5\%), were included in the model to test H6 and H7. An overall chisquare difference test for the moderator variables was first conducted for each variable (Dabholkar and Bagozzi, 2002). As shown in Table 4, the chi-square differences between the constrained and unconstrained models were $8.94(p<.05)$ for attitude toward CSR and $7.26(p$ $<.1)$ for donation amount, which indicate that there is a significant moderating effect variable somewhere in the parameters of the research model (Maiyaki, 2013). With regard to the moderating effects of donation amount, the relation between organization identification and 
gratitude was statistically stronger for those in the $5 \%$ scenario condition $(\beta=.41, p<.001)$ than for those who read the $1 \%$ scenario $(\beta=.36, p<.001)$, indicating that Hypothesis 6 was supported. Regarding the specific moderating effects of attitude toward CSR, the relation between gratitude and donation intention was statistically stronger for those who had a more positive attitude toward $\operatorname{CSR}(\beta=.45, p<.001)$ than for those who had a less positive attitude toward CSR $(\beta=.31, p<.001)$, supporting Hypothesis 7 .

Place Table 4 about here

\section{Results and discussion}

The present study empirically tested the roles of gratitude in the relationship between social identity and consumers' prosocial behavior (i.e., donation intention). The study also examined the differences in the magnitudes of the path coefficients across different levels of charity donation amount and attitude toward the CSR activity. Specifically, the organization identification-gratitude relationship was more salient when the charity donation amount of an organization was high (5\% of proceedings vs. 1\%; Palmatier et al., 2009). We also found that the gratitude - donation intention link was stronger when consumers' attitude toward the CSR activity was high (Arora and Henderson, 2007; Lichtenstein et al., 2004).

- Our findings suggest that organization identification alone does not directly increase prosocial behavior, which counters our prediction. Instead, our findings suggest that identification promotes donation through feelings of gratitude, highlighting the important role of 
moral emotions as a motivator in promoting such prosocial behavior (Bartlett and De Steno, 2006; Fredrickson, 2004; Haidt, 2003). In fact, this finding is in line with O'Reilly and Chatman's (1986) view that organization identification is not associated with financially-related prosocial behavior. Their study examined two different types of prosocial behavior: 1) the expenditure of personal time and effort (e.g., participation in extrarole activities), and 2) financial contributions. They found that organization identification was significantly associated with the prosocial behaviors related to assuming extrarole activities, but not with making financial contributions. As such, organization identification alone might not be sufficient to prompt consumers to make financial donations. Thus, findings from this study add to our knowledge about the role of organization identification in the charitable giving context.

\section{GENERAL DISCUSSION}

Our study makes several theoretical contributions. First, we show that people highly identified with an organization experience gratitude through enhanced perceptions that they have contributed to a donation. This finding provides new empirical evidence regarding the process of how a feeling of gratitude is evoked indirectly through an organization's giving (Kessler and Hollbach, 2005; Mackie et al., 2000). While the notion that a close psychological connection between the self and the group increases the experience of group-based emotions is not new, we show that consumers experience gratitude in part by associating themselves with the benefactor, not with the beneficiary. Likewise, our findings contribute to more recent theorizing of gratitude (e.g., Algoe and Haidt, 2009) by demonstrating that gratitude can be elicited in the absence of a norm of reciprocity. In other words, gratitude is still evoked by observing a good deed by an 
entity closely tied with an individual, even though he or she is not the actual beneficiary of the action (Romani et al., 2013).

Second, our findings show that charity-evoked gratitude moves beyond benefiting the benefactor in the charitable giving. Our findings highlight the lasting benefit of gratitude by showing how gratitude motivates consumers' giving intention to further benefit the organizationsupported charity (Fredrickson, 2004). While 'paying back' the benefactor or 'indebtedness' has been identified as one mechanism that explains why gratitude leads to prosocial behavior (e.g., McCullough and Tsang, 2004; Tsang, 2006), our findings provide additional support for the idea that gratitude broadens and builds to function as a moral motivator. This finding also extends the CSR literature, in which emphasis on the outcome of a CSR has been heavily focused on consumers' supportive behaviors toward the company (cf. Romani et al., 2013). We also show that the organization's donation size positively moderates the influence of organization identification on gratitude, showing that greater commitment to give back to the community can evoke more grateful feelings.

Third, we empirically show that the gratitude-prosocial behavior link is strengthened by individuals' attitude toward the CSR activity. While the relationship was significant and positive for groups with both more and less positive attitudes toward the CSR, the relationship was significantly stronger for individuals who held more favorable attitudes toward the campaign (i.e., fighting hunger). This finding highlights that the effect of gratitude on giving behavior depends on how consumers appraise a CSR campaign. As such, researchers may find attitude toward CSR an important boundary condition that can stimulate the gratitude-donation relationship. 


\section{Managerial implications}

Our findings also have several implications for managers. We utilized spectator sport teams to examine the positive function of social identity in the prosocial behavior context. Our findings show that local sport teams could be effective vehicles for leveraging prosocial behaviors in the community. Given that fans develop strong psychological connections with their favorite teams, teams' efforts to support the community by giving back could encourage fans to follow that behavior through enhanced feelings of gratitude. Local governments or charity organizations may find it useful to create strategic partnerships with local sport teams to promote desired behaviors (e.g., reducing waste for environmental sustainability, donating food or blood, etc.) that would enhance the well-being of the community. For instance, the Brazilian professional football club Sport initiated an organ donor campaign to boost the rate of organ donations in Brazil, which had been at a very low level (Downie, 2013). The club launched a campaign called the "Immortal Fans" to encourage fans to sign up for organ donation. A short video clip was created to highlight several fans who found new life due to other fans' organ donations. The fans with new life thanked the club and the video went viral to the followers of the club. As a result, more than 57,000 fans of the football club signed up as donors (Downie, 2013). This campaign highlights the strategic use of strong organization identification associated with a local football team for a good cause.

Managers should also recognize that the positive effect of gratitude on giving intention is stronger when consumers evaluate a campaign favorably. The moderating role of attitude toward the CSR campaign on the gratitude-donation link highlights that communication efforts should 
be made to create positive images and associate altruistic values with the CSR campaign. It should be noted that not all CSR campaigns promote goodwill images. When a campaign is not carefully managed, consumers might fear that CSR is a marketing gimmick, which results in negative attitudes toward the company (e.g., Forehand and Grier, 2003; Webb and Mohr, 1998). Therefore, it is important for managers to maintain or enhance positive consumer evaluations toward the CSR activity, to maximize the desired call to action in consumers.

\section{Limitations and directions for future research}

We acknowledge some limitations of the present study, which suggest avenues for future research along this line. First, the current study examined whether fans' donations would be made to the charity already receiving benefits from the organization. It remains to be examined whether gratitude evoked from organization identification could be extended to benefit another worthy charitable organization. For instance, it would be interesting to see if gratitude could motivate consumers to engage in prosocial behavior to support another local charity in the community. Second, we considered donation intentions as an outcome measure. While measuring behavioral intentions has been generally adopted in the marketing literature, we acknowledge that future research should employ actual behaviors to demonstrate the moral function of gratitude induced by an organization's charitable donation. Additionally, future studies should incorporate different types of moral emotions (e.g., other-praising moral emotions, other-condemning moral emotions; Haidt, 2003) to advance our understanding of the role of moral emotions in the charitable giving context. Different emotional dimensions might motivate different types of processing mechanisms in responding to CSR initiatives. While some positive 
emotions (e.g., pride) might motivate consumers to prefer promotion-focused messages, negative emotions (e.g., shame, guilt) would motivate consumers to prefer prevention-focused messages (Higgins, 1998). In addition, a recent study suggests that message types (prevention-focused vs. promotion-focused) promoting CSR can also impact consumer responses (Kim et al., 2012). As such, exploring additional boundary conditions (emotional dimensions, message type, etc.) in an experimental setting would further advance the current findings.

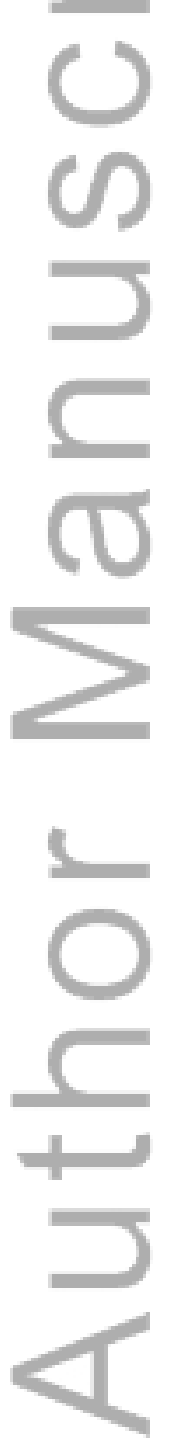




\section{REFERENCES}

Algoe SB, Haidt J. 2009. Witnessing excellence in action: The “'Other-Praising”, emotions of elevation, gratitude, and admiration. The Journal of Positive Psychology 4(2): 105-127.

Algoe S, Haidt J, Gable S. 2008. Beyond reciprocity: Gratitude and relationships in everyday life. Emotion 8(3): 425-429.

Anderson JC, Gerbing DW. 1992. Assumptions and comparative strengths of the two-step approach comment on Fornell and Yi. Sociological Methods \& Research 20(3): 321-333.

Arora N, Henderson T. 2007. Embedded premium promotion: Why it works and how to make it more effective. Marketing Science 26(4): 514-531.

Bartlett MY, DeSteno D. 2006. Gratitude and prosocial behavior helping when it costs you. Psychological Science 17(4): 319-325.

Becker TE. 2005. Potential problems in the statistical control of variables in organizational research: A qualitative analysis with recommendations. Organizational Research Methods 8(3): 274-289.

Bell SJ, Menguc B. 2002. The employee-organization relationship, organizational citizenship behaviors, and superior service quality. Journal of Retailing 78(2): 131-146.

Bloomberg Business. 2014. If the NFL Were a Real Business. Available at http://www.bloomberg.com/bw/articles/2014-09-12/if-the-nfl-were-a-real-business [accessed on 30 August 2015].

Cialdini RB, Goldstein NJ. 2004. Social influence: Compliance and conformity. Annual Review of Psychology, 55, 591-621. 
Dabholkar PA, Bagozzi RP. 2002. An attitudinal model of technology-based self-service: moderating effects of consumer traits and situational factors. Journal of the Academy of Marketing Science 30(3): 184-201.

Downie A. 2013. Fans put their hearts into organ donor campaign. Available at http://uk.mobile.reuters.com/article/UK-BigStory3/idUKBRE99L0N020131022

[accessed on 21 Apr 2015].

Emmons RA, Crumpler CA. 2000. Gratitude as human strength: Appraising the evidence. Journal of Social and Clinical Psychology 19(1): 56-69.

Folse JAG, Niedrich RW, Grau SL. 2010. Cause-related marketing: The effects of purchase quantity and firm donation amount on consumer inferences and participation intentions. Journal of Retailing 86(4): 295-309.

Forehand MR, Grier S. 2003. When is honesty the best policy? The effect of stated company intent on consumer skepticism. Journal of Consumer Psychology 13(3): 349-356.

Fortune Magazine. 2015. Fortune 500. Available at http://fortune.com/fortune500/ [access on 30 August 2015].

Fredrickson BL. 2004. Gratitude, like other positive emotions, broadens and builds. In R. A. Emmons \& M. E. McCullough (eds.), The psychology of gratitude (pp. 145-166). New York: Oxford University Press.

Giving USA Foundation. 2014. Giving USA 2014: The annual report on philanthropy for the year 2013. Available at http://www.dfwonline.org/userdata/userfiles/file/WI\%20Gives/Giving\% 20USA\%202014\%20Highlights.pdf [accessed on 21 Apr 2015].

This article is protected by copyright. All rights reserved. 
Goldenberg A., Saguy T., Halperin E. 2014. How group-based emotions are shaped by collective emotions: Evidence for emotional transfer and emotional burden. Journal of Personality and Social Psychology, 107(4): 581-596.

Goldstein NJ, Griskevicius V., Cialdini RB. 2011. Reciprocity by proxy: A novel influence strategy for stimulating cooperation. Administrative Science Quarterly, 56(3): 441-473.

Gouldner AW.1960. The norm of reciprocity: A preliminary statement. American Sociological Review, 25: 161-178.

Greenberg MS. 1980. A theory of indebtedness. In Gergen KJ, Greenberg MS, Willis RH. (eds.), Social exchange: Advances in theory and research (pp. 3-26). New York: Plenum Press.

Gruen TW, Summers JO, Acito F. 2000. Relationship marketing activities, commitment, and membership behaviors in professional associations. Journal of Marketing 64(3): 34-49.

Haidt J. 2003. The moral emotions. In Davidson RJ, Scherer KR, Goldsmith HH. (eds.), Handbook of affective sciences (pp. 852-870). Oxford: Oxford University Press.

Hair JF, Black WC, Babin BJ, Anderson RE. 2010. Multivariate data analysis (7 ${ }^{\text {th }}$ ed). New Jersey: Pearson Prentice Hall.

Haruvy E, Popkowski Leszczyc PT. 2009. Bidder motives in cause-related auctions. International Journal of Research in Marketing 26(4): 324-331.

Higgins ET. 1998. Promotion and prevention: Regulatory focus as a motivational principle. Advances in Experimental Social Psychology, 30: 1-46. 
Hirt ER, Zillmann D, Erickson GA, Kennedy C. 1992. Costs and benefits of allegiance: Changes in fans' self-ascribed competencies after team victory versus defeat. Journal of Personality and Social Psychology 63(5): 724-738.

Hu LT, Bentler PM. 1999. Cutoff criteria for fit indexes in covariance structure analysis: Conventional criteria versus new alternatives. Structural Equation Modeling: A $=$ Multidisciplinary Journal 6(1): 1-55.

Iacobucci D. 2010. Structural equations modeling: Fit indices, sample size, and advanced topics. Journal of Consumer Psychology 20(1): 90-98.

Irwin RL, Lachowetz T, Cornwell TB, Clark JS. 2003. Cause-related sport sponsorship: An assessment of spectator beliefs, attitudes, and behavioral intentions. Sport Marketing Quarterly 12(3): 131-39.

Johnson AR, Stewart DW. 2010. A reappraisal of the role of emotion in consumer behavior: Traditional and contemporary approaches. Review of Marketing Research 1: 3-33. Kessler T, Hollbach S. 2005. Group-based emotions as determinants of ingroup identification. Journal of Experimental Social Psychology 41(6): 677-685.

Kim EEK, Kang J, Mattila AS. 2012. The impact of prevention versus promotion hope on CSR activities. International Journal of Hospitality Management 31(1): 43-51.

Kline P. 2011. Principles and practice of structural equation modeling ( $3^{\text {rd }}$ ed.). New York: Guilford.

This article is protected by copyright. All rights reserved. 
Knobloch-Westerwick S, David P, Eastin MS, Tamborini R, Greenwood D. 2009. Sports

spectators' suspense: Affect and uncertainty in sports entertainment. Journal of Communication 59(4): 750-767.

Koschate-Fischer N, Stefan IV, Hoyer WD. 2012. Willingness to pay for cause-related marketing:

= the impact of donation amount and moderating effects. Journal of Marketing Research 49(6): 910-927.

Lazarus P. 1991. Progress on a cognitive-motivational-relational theory of emotion. American Psychologist, 46: 819-834.

Lichtenstein DR, Drumwright ME, Braig BM. 2004. The effect of corporate social responsibility on customer donations to corporate-supported nonprofits. Journal of Marketing 68(4):

\section{$16-32$.}

Mackie DM, Devos T, Smith ER. 2000. Intergroup emotions: Explaining offensive action tendencies in an intergroup context. Journal of Personality and Social Psychology 79(4): $602-616$.

Madrigal R. 2001. Social identity effects in a belief-attitude-intentions hierarchy: Implications for corporate sponsorship. Psychology \& Marketing 18(2): 145-165.

Maiyaki AA. 2013. Moderating effect of individualism/collectivism on the association between service quality, corporate reputation, perceived value and consumer behavioural intention. Journal of Marketing and Management 4(1): 1-20. 
McCullough ME, Emmons RA, Tsang J. 2002. The grateful disposition: A conceptual and empirical topography. Journal of Personality and Social Psychology 82(January): 112127.

McCullough ME, Kilpatrick SD, Emmons RA, Larson DB. 2001. Is gratitude a moral affect? Psychological Bulletin 127(2): 249-266.

McCullough ME, Tsang J. 2004. Parent of the Virtues? In Emmons RA, McCullough ME. (eds.), The psychology of gratitude (pp. 123-141). New York: Oxford University Press.

NBC Sports. 2015. Super Bowl XLIX sets U.S. viewership record. Available at http://profootballtalk.nbcsports.com/2015/02/02/super-bowl-xlix-sets-u-s-viewershiprecord/ [accessed on 30 August 2015].

NFL COMMUNICATIONS. NFL 2014 TV Recap. Available at http://nflcommunications.com/2014/01/08/nfl-2013-tv-recap/ [accessed on 30 August $2015]$.

O'Reilly CA, Chatman J. 1986. Organizational commitment and psychological attachment: The effects of compliance, identification, and internalization on prosocial behavior. Journal of Applied Psychology 71(3): 492-499.

Palmatier RW, Jarvis CB, Bechkoff JR, Kardes FR. 2009. The role of customer gratitude in relationship marketing. Journal of Marketing 73(5): 1-18.

Robinson MJ, Trail GT. 2005. Relationships among spectator gender, motives, points of attachment, and sport preference. Journal of Sport Management 19(1): 58-80.

This article is protected by copyright. All rights reserved. 
Romani S, Grappi S, Bagozzi RP. 2013. Explaining consumer reactions to corporate social responsibility: The role of gratitude and altruistic values. Journal of Business Ethics 114(2): 193-206.

Roy DP. 2011. Impact of congruence in cause marketing campaigns for professional sport organisations. International Journal of Sport Management and Marketing 10(1/2): 21-34. $=$

Roy DP, Graeff TR. 2003. Consumer attitudes toward cause-related marketing activities in professional sports. Sport Marketing Quarterly 12(3): 163-172.

Schlosser AE, White TB, Lloyd SM. 2006. Converting web site visitors into buyers: How web site investment increases consumer trusting beliefs and online purchase intentions. Journal of Marketing 70(3): 133-148.

Tajfel H., Tuner JC. 1986. The social identity theory of intergroup behavior. In S. Worchel \& W. G. Austin (Eds.), Psychology of intergroup relations (2 ${ }^{\text {nd }}$ ed., pp. 7-24). Chicago, IL:

\section{Nelson-Hall.}

Tangney JP, Stuewig J, Mashek DJ. 2007. Moral emotions and moral behavior. Annual Review of Psychology 58: 345-372.

Tesser A, Gatewood R, Driver M. 1968. Some determinants of gratitude Journal of Personality and Social Psychology 9(3): 233-236.

Trail GT, Anderson DF, Fink JS. 2005. Consumer satisfaction and identity theory: A model of sport spectator conative loyalty. Sport Marketing Quarterly 14(2): 98-111.

Tsang JA. 2006. Gratitude and prosocial behaviour: An experimental test of gratitude. Cognition \&Emotion 20(1): 138-148. 
Walsh G, Evanschitzky H, Wunderlich M. 2008. Identification and analysis of moderator variables: investigating the customer satisfaction-loyalty link. European Journal of Marketing 42(9/10): 977-1004.

Webb DJ, Green CL, Brashear TG. 2000. Development and validation of scales to measure attitudes influencing monetary donations to charitable organizations. Journal of the

$=$ Academy of Marketing Science 28(March): 299-309.

Webb DJ, Mohr LA. 1998. A typology of consumer responses to cause-related marketing: From skeptics to socially concerned. Journal of Public Policy and Marketing 17(2): 226-238.

Yzerbyt V, Dumont M, Wigboldus D, Gordijn E. 2003. I feel for us: The impact of categorization and identification on emotions and action tendencies. British Journal of Social Psychology 42(4): 533-549.

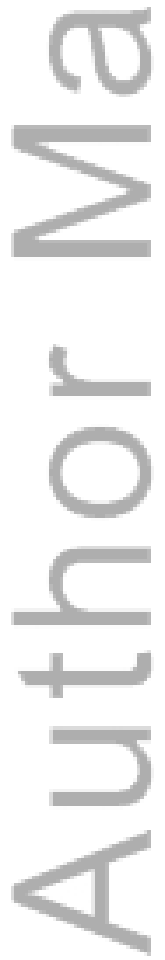

This article is protected by copyright. All rights reserved. 
Table 1. Results of confirmatory factor analysis ${ }^{\mathrm{i}}$

\begin{tabular}{|c|c|c|c|c|c|c|c|c|}
\hline Variables & CR & AVE & MSV & ASV & 1 & 2 & 3 & 4 \\
\hline $\begin{array}{l}\text { 1. Organization } \\
\text { Identification }\end{array}$ & 0.961 & 0.805 & 0.114 & 0.066 & $0.897^{\mathrm{a}}$ & & & \\
\hline 2. Gratitude & 0.963 & 0.898 & 0.295 & 0.155 & 0.338 & $0.947^{\mathrm{a}}$ & & \\
\hline 3. Donate Intention & 0.910 & 0.772 & 0.295 & 0.175 & 0.269 & 0.543 & $0.878^{\mathrm{a}}$ & \\
\hline 4. Helping Others & 0.901 & 0.610 & 0.158 & 0.076 & 0.109 & 0.239 & 0.397 & $0.781^{\mathrm{a}}$ \\
\hline $\begin{array}{l}\text { Summary of } \\
\text { Fit Indices: }\end{array}$ & $\begin{array}{l}\chi^{2} / \mathrm{df}= \\
\text { SRMR }\end{array}$ & $\begin{aligned} & 168 ; \mathrm{C} \\
= & .050 ; \mathrm{F}\end{aligned}$ & $\begin{array}{l}\mathrm{I}=.960 \\
\text { MSEA }\end{array}$ & $\begin{array}{l}\mathrm{NFI}= \\
.076 ; \mathrm{T}\end{array}$ & $\begin{array}{l}45 \\
I=.95\end{array}$ & $\mathrm{AGFI}=$. & & \\
\hline
\end{tabular}

Note. Composite Reliability (CR), Average Variance Extracted (AVE), Maximum Shared Squared Variance (MSV), Average Shared Squared Variance (ASV); ${ }^{a}$ indicates the square root of a given construct's AVE.

${ }^{\mathrm{i}}$ The study followed a set of rules to determine the appropriateness of our sample size in conducting factor analysis: (1) absolute number of cases, and (2) subject-to-variable ratio (Kline, 2011). First, Kline (2011) suggests at least 100 cases as the absolute minimum number. Second, many scholars recommend that a subject-to-variable ratio of 5:1 is appropriate. Given that the current study included 18 variables $(N /$ variables $=201 / 18=11.17$ ), the study sample $(n=201)$ met these two criteria of the minimum sample. We also took a conservative approach in examining model fit indices (e.g., CFI and TLI) since CFI and TLI are relatively less affected by sample size (Anderson and Gerbing, 1992). 
Table 2. Results of the models with and without control variable

\begin{tabular}{|c|c|c|c|c|}
\hline \multirow{2}{*}{$=$} & \multicolumn{2}{|c|}{ Model without control variable } & \multicolumn{2}{|c|}{ Model with control variable } \\
\hline & $\begin{array}{l}\text { Standardized } \\
\text { regression coefficient } \\
(\beta)\end{array}$ & t-value & $\begin{array}{l}\text { Standardized } \\
\text { regression coefficient } \\
(\beta)\end{array}$ & t-value \\
\hline $\begin{array}{l}\text { - Organization identification } \rightarrow \text { Gratitude } \\
(\mathrm{H} 3)\end{array}$ & $.335^{* * *}$ & 4.84 & $.338 * * *$ & 4.87 \\
\hline - Gratitude $\rightarrow$ Donation intention $(\mathrm{H} 4)$ & $.497 * * *$ & 5.90 & $.462 * * *$ & 5.94 \\
\hline $\begin{array}{l}\text { - Organization identification } \rightarrow \text { Donation } \\
\text { intention (H5) }\end{array}$ & .099 & 1.48 & .088 & 1.31 \\
\hline $\begin{array}{l}\text { - Attitude toward helping others } \rightarrow \\
\text { Donation intention (control variable's } \\
\text { relation to outcome variable) }\end{array}$ & & & $.290 * * *$ & 3.75 \\
\hline $\begin{array}{l}\text { Summary of fit indices for the proposed } \\
\text { models tested: }\end{array}$ & \multicolumn{2}{|c|}{$\begin{array}{l}\chi^{2} / \mathrm{df}=3.387 ; \mathrm{CFI}=.911 ; \mathrm{NFI}=.960 ; \\
\mathrm{SRMR}=.034 ; \mathrm{RMSEA}=.109 ; \\
\mathrm{TLI}=.955\end{array}$} & \multicolumn{2}{|c|}{$\begin{array}{l}\chi^{2} / \mathrm{df}=2.220 ; \mathrm{CFI}=.967 ; \mathrm{NFI}=.943 ; \\
\text { SRMR }=.079 ; \mathrm{RMSEA}=.078 ; \\
\text { TLI }=.957\end{array}$} \\
\hline
\end{tabular}

Note. $* p<0.05, * * p<0.01$, and $* * * p<0.001$. 
Table 3. Parsimonious basic model effects

\begin{tabular}{|c|c|c|c|c|}
\hline$=$ & $\begin{array}{l}\text { Standardized } \\
\text { regression } \\
\text { coefficient }(\beta)\end{array}$ & t-value & Hypothesis & Support \\
\hline - Organization identification $\rightarrow$ Gratitude & $.342 * * *$ & 4.92 & $\mathrm{H} 4$ & Supported \\
\hline - Gratitude $\rightarrow$ Donation intention & $.495 * * *$ & 6.60 & H5 & Supported \\
\hline $\begin{array}{l}\text { - Organization identification } \rightarrow \text { Donation } \\
\text { intention }^{\text {ii }}\end{array}$ & .088 & 1.31 & H6 & Not supported \\
\hline - Helping others $\rightarrow$ Donation intention & $.297 * * *$ & 3.81 & $\mathrm{n} / \mathrm{a}$ (control factor) & \\
\hline $\begin{array}{l}\text { Summary of fit indices for the proposed model } \\
\text { tested: }\end{array}$ & \multicolumn{4}{|c|}{$\begin{array}{l}\chi^{2} / \mathrm{df}=2.215 ; \mathrm{CFI}=.967 ; \mathrm{NFI}=.942 \\
\mathrm{SRMR}=.079 ; \mathrm{RMSEA}=.078 ; \mathrm{TLI}=.957\end{array}$} \\
\hline
\end{tabular}

Note. $* p<0.05, * * p<0.01$, and $* * * p<0.001$

${ }^{\text {ii }}$ To obtain a parsimonious final model, we eliminated the non-significant path (H5: $\beta=.088$, see Table 2$)$. After eliminating the path in the proposed model, we re-estimated the hypothesized structural model with the addition of the control variable (i.e., attitude toward helping others) 
Table 4. Chi-square difference tests: Donation amount (1\% vs. 5\%) and Attitude toward organization's charity (Low vs. High)

\begin{tabular}{|c|c|c|c|c|c|c|}
\hline \multirow{2}{*}{1} & \multicolumn{3}{|c|}{ Donation amount (H6) } & \multicolumn{3}{|c|}{ Attitude toward organization's charity $(\mathrm{H7})$} \\
\hline & $\begin{array}{c}\text { Fully } \\
\text { Constrained } \\
\text { model }\end{array}$ & $\begin{array}{l}\text { Unconstrained } \\
\text { model }\end{array}$ & $\begin{array}{c}\Delta \chi^{2} \\
(\mathbf{d f}=3)\end{array}$ & $\begin{array}{c}\text { Fully } \\
\text { Constrained } \\
\text { model }\end{array}$ & $\begin{array}{c}\text { Unconstrained } \\
\text { model }\end{array}$ & $\Delta \chi^{2}(\mathbf{d f}=\mathbf{3})$ \\
\hline Fit index: & & & & & & \\
\hline Chi-square (df) & $397.045(237)$ & $389.785(234)$ & $7.260^{\dagger \mathrm{iii}}$ & $440.790(237)$ & $431.847(234)$ & $8.943 *$ \\
\hline $\mathrm{CFI}=$ & .963 & .964 & & .952 & .953 & \\
\hline TLI & .952 & .953 & & .938 & .939 & \\
\hline IFI & .964 & .965 & & .953 & .954 & \\
\hline RMSEA & .058 & .058 & & .066 & .065 & \\
\hline
\end{tabular}

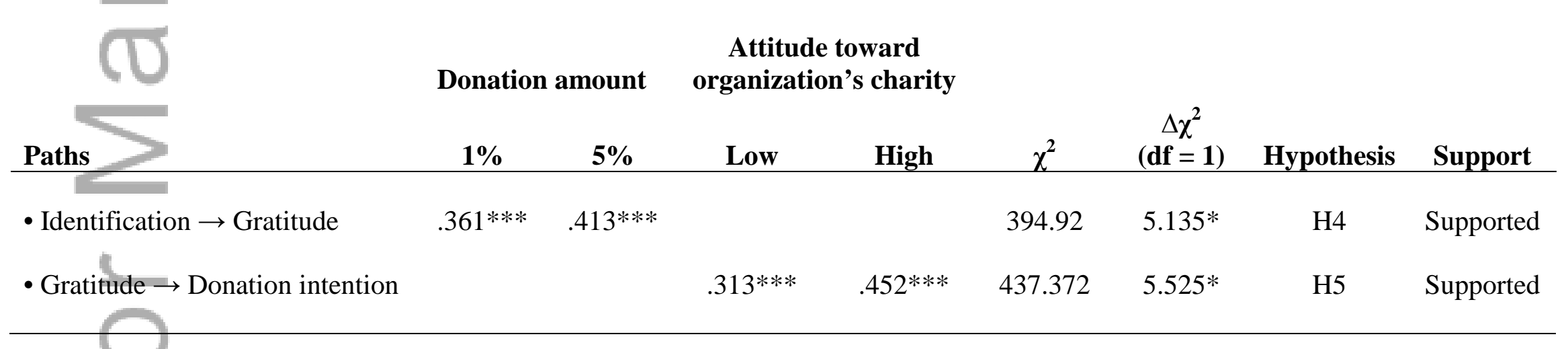

iii The chi-square difference between the fully constrained model and the unconstrained model on donation amount was 7.260, with a $p$ value of .064. We used 0.1 as a p-value threshold (cf. Walsh et al., 2008), then continued to test the difference on the proposed path from Identification to Gratitude. The results showed that the difference on the proposed path was significant at $p<0.05$.

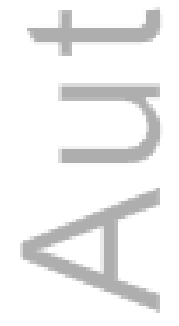




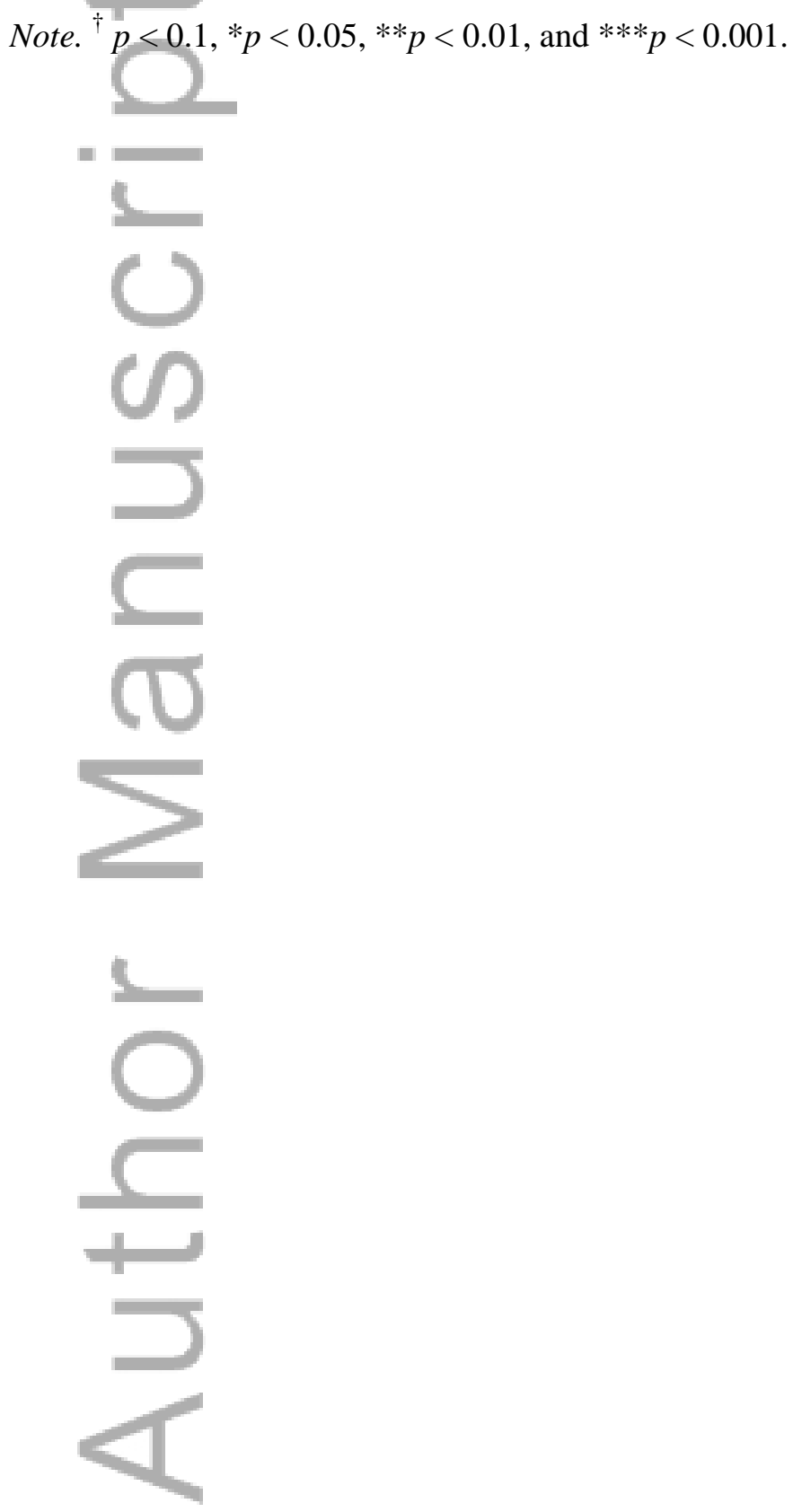

This article is protected by copyright. All rights reserved. 


\section{APPENDIX A}

\section{Scenarios}

\section{Study 1}

\section{[Local Charity]}

Team X announces that it will partner with the local Feeding America-affiliated food bank for the next five years. Each year, 5\% of the proceeds from merchandise and ticket sales will be donated to the local food bank. It is expected that Team $\mathrm{X}$ will generate more than $\$ 7$ million for the local charity over the next five years.

-

About Feeding America

Feeding America's mission is to feed America's hungry through a nationwide network of member food banks and engage our country in the fight to end hunger.

[International Charity]

Team X announced that it will partner with the World Food Programme (WFP) for the next five years. Each year, $5 \%$ of the proceeds from merchandise and ticket sales will be donated to the WFP. It is expected that Team $\mathrm{X}$ will generate more than $\$ 7$ million to the charity over the next five years.

About the World Food Programme

The World Food Programme is the food aid arm of the United Nations system and the world's largest humanitarian agency fighting hunger around the globe.

\section{Study 2}

\section{[5\% condition]}

Team $X$ announces that it will partner with the local Feeding America-affiliated food bank for the next five years. Each year, $5 \%$ of the proceeds from merchandise and ticket sales will be donated to the local food bank. It is expected that Team X will generate more than $\$ 10$ million for the local charity over the next five years.

About Feeding America

Feeding America's mission is to feed America's hungry through a nationwide network of member food banks and engage our country in the fight to end hunger.

[1\% condition]

Team X announces that it will partner with the local Feeding America-affiliated food bank for the next five years. Each year, $1 \%$ of the proceeds from merchandise and ticket sales will be donated to the local food bank. It is expected that Team X will generate more than $\$ 2$ million for the local charity over the next five years. 
About Feeding America

Feeding America's mission is to feed America's hungry through a nationwide network of member food banks and engage our country in the fight to end hunger.

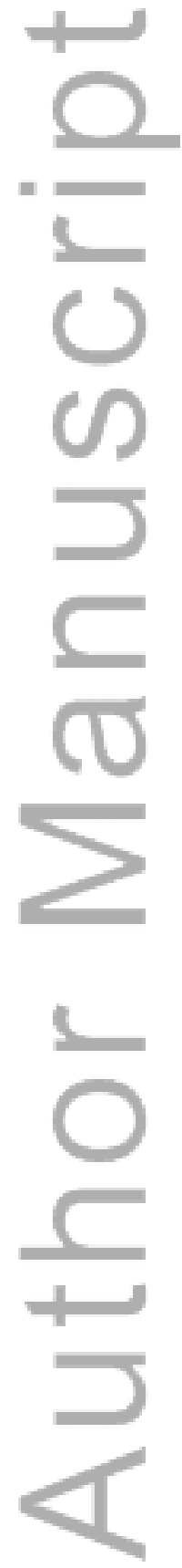




\section{APPENDIX B}

\section{Questionnaires}

[Team Identification]

Being a fan of TEAM X (team of your choice) is very important to me.

I am a committed fan of TEAM X.

I consider myself to be a "real" fan of TEAM X.

[Gratitude]

I am grateful for TEAM X.

I am thankful for TEAM X.

I feel a sense of gratitude toward TEAM X.

[Perceived Donation Contribution]

To what extent do you feel involved with the NFL's donation to Feeding America? $(1=$ not involved at all; $7=$ involved very much)

How much do you feel you have contributed to the NFL's donation to Feeding America? $(1=$ not contributed at all; 7 = contributed very much)

[Donation Intention]

It is possible that I will donate my money to Feeding America.

It is likely that I will donate my money to Feeding America.

It is likely that I will encourage my friends to donate money to Feeding America.

[Attitude toward the Organization's Charity]

Overall, my attitude toward TEAM X sponsoring the charity is bad/good; negative/positive;

unfavorable/favorable; and likable/unlikable (reversed item).

[Perceived Investment]

The amount of effort invested by TEAM X into sponsoring Feeding America seems to be a great deal.

The amount of time invested by TEAM X into sponsoring Feeding America seems to be a great deal.

The amount of money invested by TEAM X into sponsoring Feeding America seems to be a great deal.

[Attitude toward Helping Others]

People should be willing to help others who are less fortunate.

Helping troubled people with their problems is very important to me.

People should be more charitable toward others in society.

People in need should receive support from others.

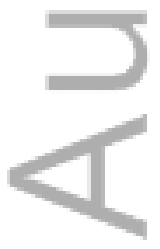

